\title{
Feasibility of STEM Teaching Kit for Heat Material Through Simple Technology Design
}

\author{
Lusy Rahmawati ${ }^{1, *}$ Insih Wilujeng ${ }^{2}$ \\ ${ }^{1}$ Physics Education, Graduate School, Universitas Negeri Yogyakarta, Jalan Colombo No. 1, Yogyakarta 55281, \\ Indonesia \\ ${ }^{2}$ Science Education, Graduate School, Universitas Negeri Yogyakarta, Jalan Colombo No. 1, Yogyakarta 55281, \\ Indonesia \\ *Corresponding author. Email: lusyrahmawati.2018@student.uny.ac.id
}

\begin{abstract}
The government needs to modernize the education system to equip 21st-century skills that can meet the challenges of the industrial revolution 4.0. The Science, Technology, Engineering, and Mathematics (STEM) approach is one of the recommended learning approaches to help the success of 21 st-century skills. In preparing students to acquire $21 \mathrm{st}-$ century skills in the era of the industrial revolution 4.0, teachers need to arrange teaching kits to facilitate learning activities. The STEM teaching kit for heat material through simple technological designs has not been developed, so the researchers took the initiative to develop STEM teaching kit for heat material through simple technology design. This research is part of the development of STEM teaching kit for heat material through simple technology design to enhance design abilities and data literacy. This research aims to determine the feasibility of teaching kits that include syllabus, lesson plans, and student worksheets. The data analysis was descriptive qualitative with the feasibility test of the teaching kit using expert judgment. The results of the feasibility show that the teaching kits developed are feasible and can be implemented in the heat material physics learning activities through a simple technology design using the STEM approach.
\end{abstract}

Keywords: Feasibility, STEM, Teaching Kit, Heat Material, Simple Technology Design.

\section{INTRODUCTION}

The world is currently entering a new industrial era that is marked by the era of digitization in various sectors of life, especially in Indonesia [1][2]. Some experts define this industrial revolution 4.0 era [3][4]. The era of the industrial revolution 4.0 was followed by the development of science and technology, so that it has a big impact on human life [5]. The digital technology support has many conveniences and innovations that can be obtained [6]. The implementation of the industrial revolution poses challenges, especially in the field of education in Indonesia. Among others, infrastructure in education field is not evenly distributed, the mindset of the actors, especially the incumbents, it has not changed, so It needs support from regulators. However, regulators must also learn to follow changes in this era of disruption, namely about disruption strategies to create new jobs and competitiveness that can only be built in new ways as well. [7].
The government needs to modernize the education system for the industrial revolution 4.0 in the 21 st century and preparing graduates who are able to meet the challenges of the industrial revolution 4.0 [8]. The Science, Technology, Engineering, and Mathematics (STEM) approach is one of the recommended learning approaches to help the success of 21st century skills [9]. Learning with the STEM approach is suitable to be applied in the classroom, because students can be taught practically in a project form so that students' experience can be got directly during learning process [10]. One of the recommended learning models in accordance with the objectives of the 2013 curriculum and the development of 21 st century learning in STEM-based learning is discovery learning model [11]. This learning model is a learning model that has the same syntax, namely studentcentered learning [12].-Through learning using the STEM integrated discovery learning model, students are interested in and get a memorable learning experience that raises motivation and interest in learning so that students' learning outcomes increase. [13][14]. 
Teachers must have good process skills in realizing 21 st-century learning. Process skills can be interpreted as teacher skills in presenting learning that can provide meaningful and enjoyable learning experiences for students [15]. The conditions in the classroom that are too monotonous, the children are forced to sit neatly for hours listening to the teacher devoting knowledge, allowing students to feel they are in another world. This condition causes middle school students to view physics as a difficult, scary, unpleasant and boring subject [16]. Learning physics, especially on heat material is considered difficult to learn by students [17]. Temperature and heat are materials whose principles can be applied in various fields of technology [18]. Technology consists of two levels, namely high-level technology and simple technology, where the process is not too complicated. Simple technology can be created from objects that are widely available in the environment, such as cans, plastics, and so forth [19]. Educators need to develop teaching kits to link physics material with technological developments and other sciences as well as a 21 st century solution in the era of the industrial revolution 4.0[18]. In physics, there is an integration between physics concepts, mathematical concepts, how to assemble equipment to produce innovative technology [20]. Some simple technology actually can be created from objects that are widely available in the environment, such as cans, plastics, and so forth [19]. This innovating teaching kits to support the implementation of the learning process is one way to improve the quality of education [21]. Currently, there are enough teaching kits and innovative thinking to improve the quality of education in this country, but this is still lacking due to the fact that there are still many students who are less able to follow lessons well in class [22].

The results showed that the development of STEM teaching kits on temperature sub material was feasible and effective for class XI MIPA students [18]. Similar research also shows that the experimental class using STEM-based science teaching kits has a greater or better $\mathrm{N}$-gain average than the control class [23]. Other research also shows that STEM-based learning can increase students' interest and activeness in physics lessons so that it can improve 21st century competency [24]. The integration of STEM parts can have a positive effect on learning, especially in terms of improving student learning outcomes in science and technology [25]. Research on STEM integration in discovery learning is still rarely done [13], so it is necessary to develop STEM teaching kits by integrating discovery learning models using simple technology designs. STEM teaching kits through a simple heat technology design developed in this study include: syllabus, lesson plan (RPP), and student worksheets (LKPD). This study aims to determine the feasibility of the STEM teaching kits for heat material through a simple technology design.

\section{METHOD}

This study uses a development research method with the 4D model, namely define, design, development, and disseminate [26]. This development research did not reach the dissemination stage. This research procedure consists of three stages, namely the stage of defining, developing teaching kits, and assessing the feasibility of teaching kits. with the research flow described in Figure 1.

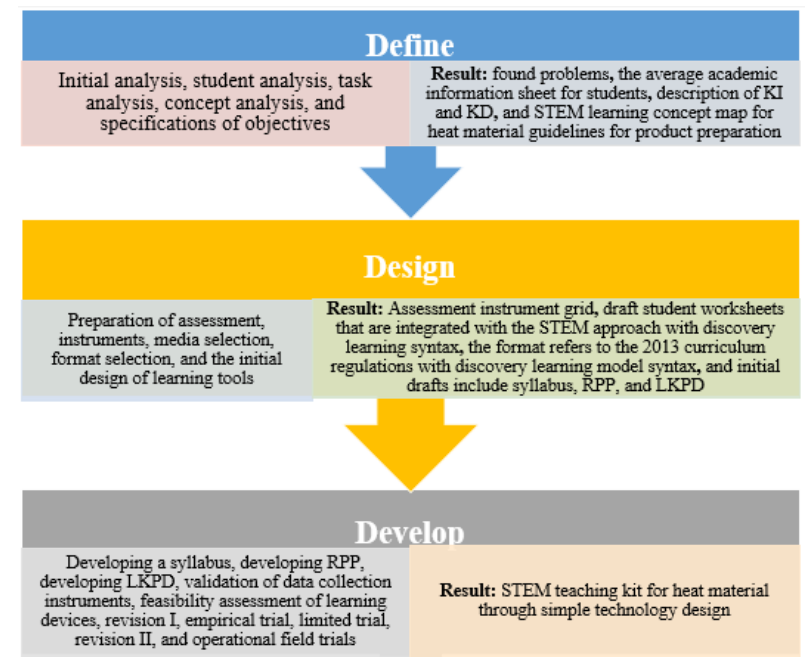

Figure 1 Research design

The assessment of teaching kits developed was carried out by 3 expert lecturers from Physics Education, Yogyakarta State University Postgraduate Program and 3 physics teachers. The assessment is carried out with the criteria of 4 rating scales, the minimum score is 1 and the maximum is 4 . Suggestions from the assessors are used as guidelines and considerations for revising the product. Data analysis techniques using equations (1): $\bar{X}=\frac{\Sigma X}{n}$

With, the sum score $(\Sigma X)$ for each aspect in assessment sheets is divided by 6 assessors as judgements. The average value $(\bar{X})$ for each aspect can be obtained with equation and $n$ is the number of assessors or responses. Determine the criteria for the assessment results based on Table 1 below

Table 1. Actual Score Conversion Guidelines

\begin{tabular}{|c|l|}
\hline \multicolumn{1}{|c|}{ Interval score } & \multicolumn{1}{c|}{ Category } \\
\hline$X>\overline{X_{t}}+1.8 S B i$ & Very Feasible \\
\hline$\overline{X_{t}}+0.6 S B i<X \leq \overline{X_{t}}+1.8 S B i$ & Feasible \\
\hline$\overline{X_{t}}-0.6 S B i<X \leq \overline{X_{t}}+0.6 S B i$ & Moderate \\
\hline$\overline{X_{t}}-1.8 S B i<X \leq \overline{X_{t}}-0.6 S B i$ & Less Feasible \\
\hline$X \leq \overline{X_{t}}-1.8 S B i$ & Very Less Feasible \\
\hline
\end{tabular}

With, $\overline{X_{t}}$ for Ideal mean $=1 / 2($ maximum score + minimum score), $S B i$ for ideal standard deviation $=$ 

score

(maximum score + minimum score), and $X$ for actual

\section{RESULT AND DISCUSSION}

The development result of this development is in the form of a heat material STEM teaching kits through a simple technology design. From the literature study, it was found that in facing the challenges of the $21 \mathrm{st}$ century, students must have 21 st century skills. The STEM approach is an approach capable of actualizing 21 st century skills. In line with the literature study, it was found that the STEM approach is one of the approaches capable of actualizing 21 st century skills. The results of interviews with physics educators at MAN 1 Yogyakarta show that educators have never applied the STEM approach in learning. Physics educators also do not have STEM learning instrument. The results of this interview are reinforced by the results of the needs analysis in previous studies which show that not many educators are implementing STEM-based learning in their schools [27].

The next stage is the design stage. At the design stage, a physics learning instrument consist of a syllabus, lesson plans and student worksheets. Furthermore, a measurement instrument was prepared in the form of a teaching kits feasibility assessment sheet. The teaching kits designed is based on the discovery learning model with the STEM approach. The results of the initial product design are used as the initial draft of the teaching kits.

The last stage is the develop stage. At the develop stage, teaching kits that have been compiled at the design stage are then assessed for their feasibility by 3 expert lecturers and 3 physics teachers. The learning instrument have been reviewed and then corrected based on suggestions and comments from expert lecturers and practitioners. At this research stage has been limited it to the stage to determine the feasibility of teaching kits products. The results of data analysis in research on teaching kits development can be seen in Figure 2, Figure 4, and Figure 7.

\subsection{Results of the Assessment of Teaching Kits Feasibility}

The average score data obtained from the three expert lecturers and the three expert practitioners can be converted into five scale qualitative data that be obtained by entering the maximum and minimum score values to determine $\overline{X_{t}}$ and $S B i$. The number of criterion items per aspect of the assessment of the feasibility of teaching kitss is 1 criterion item (ideal maximum score $=4$ and ideal minimum score $=1, \overline{X_{t}}=2.5$, and $S B i=0.5$ ), in order to obtain the interval criteria for each category listed in Table 2

Table 2. Interval Criteria for Each Aspect of Teaching Kits

\begin{tabular}{|l|l|l|l|}
\hline No & Score Interval & Average Score & Category \\
\hline 1 & $X>\overline{X_{t}}+1.8 \mathrm{SBi}$ & $X>3.4$ & Very Feasible \\
\hline 2 & $\overline{X_{t}}+0.6 \mathrm{SBi}<\mathrm{X} \leq \overline{X_{t}}+1.8 \mathrm{SBi}$ & $2.8<X \leq 3.4$ & Feasible \\
\hline 3 & $\overline{X_{t}}-0.6 \mathrm{SBi}<X \leq \overline{X_{t}}+0.6 \mathrm{SBi}$ & $2.2<X \leq 2.8$ & Moderate \\
\hline 4 & $\overline{X_{t}}-1.8 \mathrm{SBi}<X \leq \overline{X_{t}}-0.6 \mathrm{SBi}$ & $1.6<X \leq 2.2$ & Less Feasible \\
\hline 5 & $X \leq \overline{X_{t}}-1.8 \mathrm{SBi}$ & $X \leq 1.6$ & Very Less Feasible \\
\hline
\end{tabular}

\subsubsection{Result of the Syllabus Feasibility Assessment}

Aspects in the syllabus were assessed by 3 expert lecturers from Physics Education, Yogyakarta State
University Postgraduate Program and 3 physics teachers. The results of the syllabus feasibility assessment were calculated the average score and converted to a four-scale assessment, the results of which can be observed in Table 3.

Table 3. Results of the Syllabus Feasibility Assessment

\begin{tabular}{|l|l|l|}
\hline Aspects of the Syllabus & Average Score & Category \\
\hline Identity Syllabus & 4.00 & Very Feasible \\
\hline Core Competencies and Basic Competencies & 3.83 & Very Feasible \\
\hline Learning materials & 4.00 & Very Feasible \\
\hline Indicator & 3.83 & Very Feasible \\
\hline STEM integration & 3.83 & Very Feasible \\
\hline Learning Activities & 4.00 & Very Feasible \\
\hline Time Allocation & 4.00 & Very Feasible \\
\hline Learning Resources & 4.00 & Very Feasible \\
\hline Assessment & 3.67 & Very Feasible \\
\hline Average & 3.91 & Very Feasible \\
\hline
\end{tabular}

Based on Table 3, it can be observed that the results of the syllabus feasibility assessment obtained an average value of 3.91 which is included in the very feasible category. In the preparation of this syllabus, researchers 
received input from expert lecturers and practitioners, namely to add STEM approach steps and discovery learning models to learning activities. Details of the revised syllabus are in Figure 2. This research is in line with research which shows that the eligibility results of the STEM syllabus are declared feasible [24] [28][29].

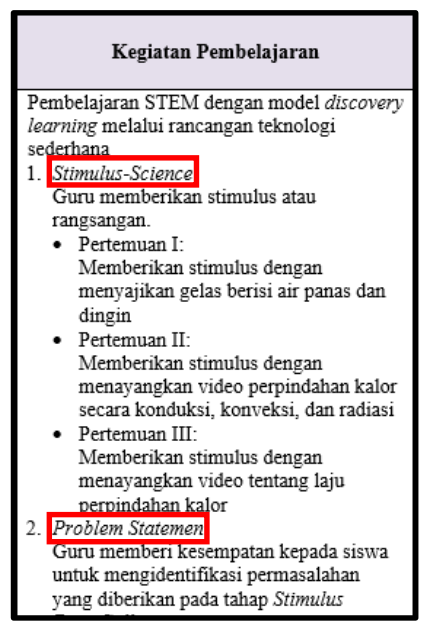

Figure 2. Learning Steps After Revision

\subsubsection{Result of the RPP Feasibility Assessment}

The results of the feasibility assessment of each aspect of the lesson plan can be observed in Table

Table 4. Result of the RPP Feasibility Assessment

\begin{tabular}{|l|l|l|}
\hline RPP Aspects & $\begin{array}{l}\text { Average } \\
\text { Score }\end{array}$ & Category \\
\hline RPP identity & 4.00 & Very Feasible \\
\hline Indicator & 3.83 & Very Feasible \\
\hline Aim & 3.67 & Very Feasible \\
\hline Learning materials & 3.83 & Very Feasible \\
\hline Learning methods & 4.00 & Very Feasible \\
\hline Learning Resources & 4.00 & Very Feasible \\
\hline $\begin{array}{l}\text { Preliminary } \\
\text { activities }\end{array}$ & 3.83 & Very Feasible \\
\hline Learning Activities & 3.83 & Very Feasible \\
\hline Closing Activities & 3.83 & Very Feasible \\
\hline Assessment & 4.00 & Very Feasible \\
\hline STEM integration & 3.67 & Very Feasible \\
\hline $\begin{array}{l}\text { Integrating } \\
\text { Discovery Learning } \\
\text { in STEM }\end{array}$ & 3.83 & Very Feasible \\
\hline Language & & \\
\hline Average & $\mathbf{3 . 8 7}$ & Very Feasible \\
\hline
\end{tabular}

Table 4 shows the results of the RPP feasibility assessment obtained an average value of 3.87 which is included in the very feasible category. The preparation of this lesson plan received input from expert lecturers and practitioners, namely that in each meeting, the objectives and materials must be included and then integrated the STEM approach in the lesson plan. The details of the revised RPP section are in Figure 3 and Figure 4. This research is in line with the research which shows that the results of the assessment of the feasibility of the RPP STEM which are based on the RPP feasibility test criteria are declared worthy of being used as a guideline for implementing temperature material learning. [18] [24] [30].

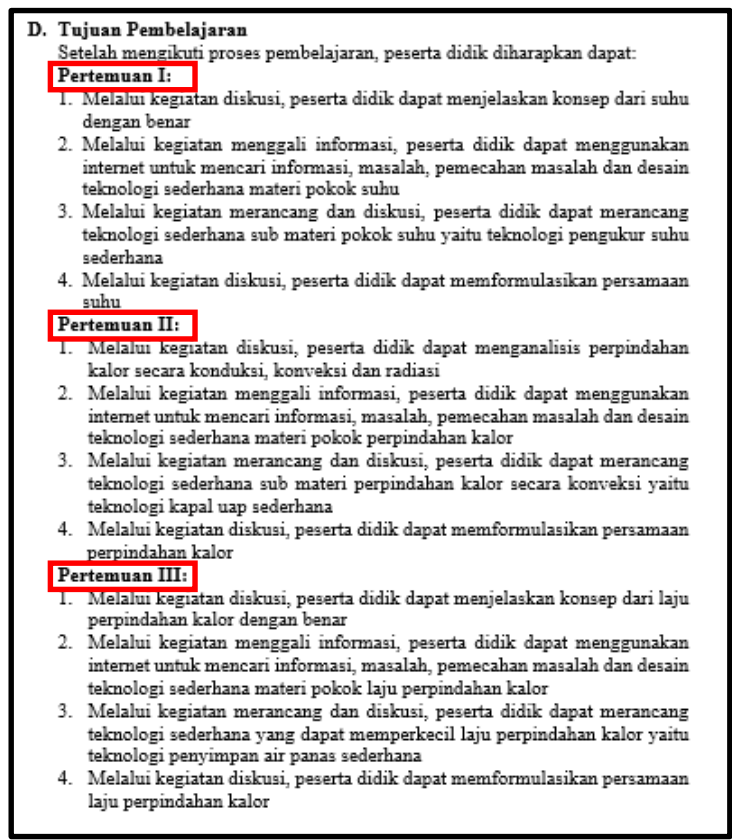

Figure 3. Writing Learning Objectives After Revision

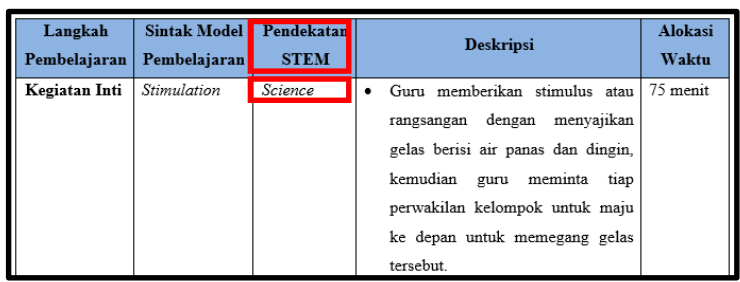

Figure 4. Integrating STEM into RPP After Revision

\subsubsection{Results of the LKPD Feasibility Assessment}

The results of the feasibility assessment for each aspect of the LKPD can be observed in Table 5.

Table 5. Results of the LKPD Feasibility Assessment

\begin{tabular}{|l|c|l|}
\hline LKPD Aspects & $\begin{array}{l}\text { Average } \\
\text { Score }\end{array}$ & Category \\
\hline Content Feasibility & 4.00 & Very Feasible \\
\hline $\begin{array}{l}\text { Language } \\
\text { Feasibility }\end{array}$ & 3.67 & Very Feasible \\
\hline Serving Feasibility & 3.83 & Very Feasible \\
\hline STEM integration & 4.00 & Very Feasible \\
\hline $\begin{array}{l}\text { Integrating } \\
\text { Discovery Learning } \\
\text { in STEM }\end{array}$ & 4.00 & Very Feasible \\
\hline Format & 4.00 & Very Feasible \\
\hline Physical Quality & 3.67 & Very Feasible \\
\hline Average & 3.88 & Very Feasible \\
\hline
\end{tabular}

Based on Table 5, it can be observed that the results of the LKPD feasibility assessment obtained an average 
value of 3.88 which is included in the very feasible category. However, if we pay attention to the linguistic and physical aspects, it gets the lowest average score of 3.67. This is partly because the LKPD still contains errors in the form of unclear images. Details of the revised LKPD are in Figure 5 and Figure 6. This research is in line with the research which shows that LKPD integrated STEM material temperature and change is declared worthy of being used as a reference in learning to face the challenges of the 21 st century [28]. Similar research also shows that the results of the feasibility assessment of the LKPD STEM temperature sub-material from the three expert lecturers and the three practitioners are declared feasible to be implemented in students [18] [24] [30].

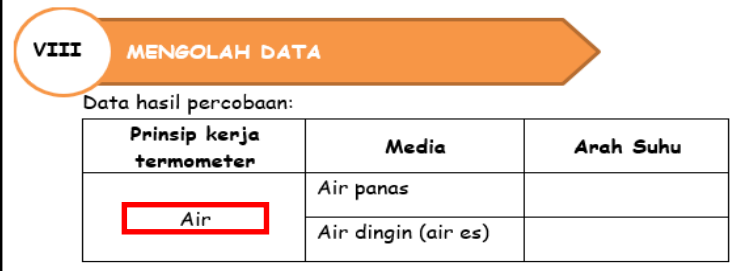

Figure 5. Writing on the experimental data after revision

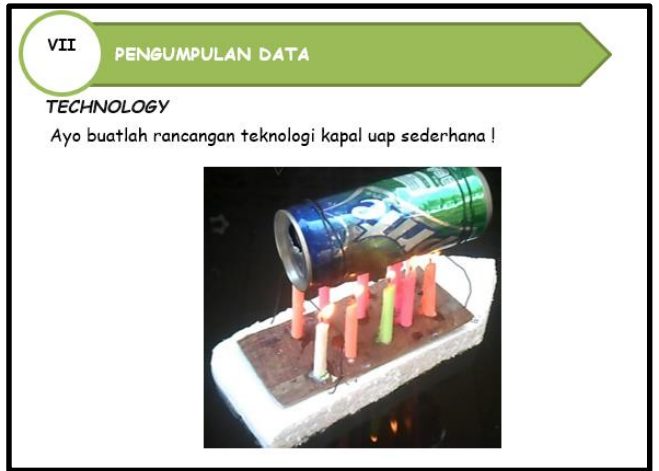

Figure 6. Illustration of Simple Steam Ship After Revision

\section{CONCLUSION}

Based on the results of the feasibility assessment of teaching kit which include syllabus, lesson plans, and student worksheets, it shows that the teaching kit developed have a very feasible category. This indicates that the teaching kit is suitable for use in heat learning for class XI SMA/ MA. This research can be continued to apply teaching kits in the classroom.

\section{ACKNOWLEDGMENTS}

Special thanks to Dr. Insih Wilujeng, M.Pd as the supervisor who has been patient in guiding the writing of this article. In addition, the author would like to thank Prof. Dr. Jumadi, M.Pd., Dr. Sukardiyono, M.Sc., and Dr. Supahar, M.Si as the expert validator and to Ari Satriana, M.Pd, Drs. Giyanto, and Na'im Uswatun Hasanah, S.Pd as practitioner validators who have provided assessments, suggestions, and corrections for the improvement of teaching kits development products

\section{REFERENCES}

[1] Utami A W, Suyasa, P T Y and Idulfilastri R M 2020 Voice Climate: The Basic Conditions When Employees Have Readiness to Change Wholeheartedly In Tarumanagara International Conference on the Applications of Social Sciences and Humanities (TICASH 2019) pp 418-425) Atlantis Press

https://doi.org/10.2991/assehr.k.200515.073

[2] Anikarnisia N M and Wilujeng I 2020 Need assessment of STEM education based based on local wisdom in junior high school In Journal of Physics: Conference Series Vol 1440 No 1 p 012092 IOP Publishing https://doi.org/10.1088/1742-6596/1440/1/012092

[3] Alhamuddin A, Tsaury A M, Surbiyantoro E and Murniati A 2020 Competence of Islamic Higher Education Graduates from the Perspectives of Stakeholders in the Era of Industrial Revolution 4.0. In 2nd Social and Humaniora Research Symposium (SoRes 2019) pp 117-120 Atlantis Press https://doi.org/10.2991/assehr.k.200225.025

[4] Sari W K and Wilujeng I 2020 Education change in the industry 4.0: Candidate science teacher perspective In Journal of Physics: Conference Series Vol 1440 No 1 p 012090 IOP Publishing https://doi.org/10.1088/1742-6596/1440/1/012090

[5] Ghufron G 2018 Revolusi Industri 4.0: Tantangan, Peluang, Dan Solusi Bagi Dunia Pendidikan In Seminar Nasional dan Diskusi Panel Multidisiplin Hasil Penelitian dan Pengabdian Kepada Masyarakat 2018 Vol 1 No 1

[6] Lasi H, Fettke P, Kemper, H G, Feld T and Hoffmann M 2014 Industry 4.0 Bus Inf Syst Eng 6: 239-242

https://doi.org/10.1007/s12599-014-0334-4

[7] Risdianto E 2019 Analisis Pendidikan Indonesia Di Era Revolusi Industri 4.0 No Apri pp 0-16 https://doi.org/10.36835/attaqwa.v16i2.55

[8] Sujadi I 2019 Peran Pembelajaran Matematika Pada Penguatan Nilai Karakter Bangsa Di Era Revolusi Industri 4.0 Pros. Silogisme vol 1 (1)

[9] Wan Husin W N F, Mohamad Arsad N, Othman O, Halim L, Rasul M S, Osman K and Iksan Z 2016 Fostering students' 21st century skills through Project Oriented Problem Based Learning (POPBL) in integrated STEM education program In Asia- 
Pacific Forum on Science Learning \& Teaching Vol 17 No 1 pp 1-19

[10] Septiyani N N R 2018 Implementasi Pendekatan Pembelajaran STEM untuk Meningkatkan Skill Argumentasi pada Siswa SMA

[11] Abdurrahman F, Ariyani H, Maulina and Nurulsari N 2019 Design and validation of inquiry-based STEM learning strategy as a powerful alternative solution to facilitate gifted students facing 21st century challenging J. Educ. Gift. Young Sci vol 7 no 1 pp 33-56

https://doi.org/10.17478/jegys.513308

[12] Ott L E, Carpenter T S, Hamilton D S and LaCourse W R 2018 Discovery learning: Development of a unique active learning environment for introductory chemistry Journal of the Scholarship of Teaching and Learning 18(4) pp 161-180

https://doi.org/10.14434/josotl.v18i4.23112

[13] Hapizoh 2019 Penerapan Discovery Learning Terintegrasi STEM untuk Meningkatkan Hasil Belajar Peserta Didik SMP Negeri 26 Palembang Prosiding Seminar Nasional Pendidikan Progr. Pascasarj. Universitas PGRI Palembang pp 293304

[14] Rahmawati L, Wilujeng I and Satriana A 2020 Application of STEM learning approach through simple technology to increase data literacy In Journal of Physics: Conference Series Vol 1440 No 1 p 012047 IOP Publishing. https://doi.org/10.1088/1742-6596/1440/1/012047

[15] Rozi F and Hanum C B 2019 Pembelajaran IPA SD Berbasis HOTS (Higher Order Thinking Skills) Menjawab Tuntutan Pembelajaran Di Abad 21 in Seminar Nasional Pendidikan Dasar Universitas Negeri Medan.

[16] Ayuningtyas P 2015 Pengembangan Perangkat Pembelajaran Fisika dengan Model Inkuiri Terbimbing untuk Melatihkan Keterampilan Proses Sains Siswa SMA Pada Materi Fluida Statis Pendidik. Sains Pascasarja. Univ. Negeri Surabaya vol. 4 no 2 pp 636-647 https://doi.org/10.26740/jpps.v4n2.p636-647

[17] Ariani D and Meutiawati I 2020 Pengembangan Lembar Kerja Peserta Didik ( LKPD ) berbasis discovery learning pada materi $J$. Phi vol 1 no 3 pp 13-19

https://doi.org/10.22373/p-jpft.v1i1.6477

[18] Shindharatna S D 2018 Pengembangan Perangkat Pembelajaran Science, Technology, Engineering and Mathematics pada Sub Materi Suhu Kelas XI
SMA Universitas Negeri Malang Skripsi Jurusan Fisika-Fakultas MIPA UM

[19] Sopiah S T 2018 Teknologi Sederhana untuk Kehidupan Sehari-hari

[20] Bashooir K and Supahar 2018 Validitas dan Reliabilitas Instrumen Asesmen Kinerja Literasi Sains Pelajaran Fisika Berbasis STEM J. Penelit. dan Eval. Pendidik vol 22 no 2 pp 219-230 https://doi.org/10.21831/pep.v22i2.19590

[21] Mutawali N 2015 Perangkat Pembelajaran Inovatif dalam Pembelajaran IPA Terpadu untuk Menggali Kemampuan Berpikir Kreatif Siswa

[22] Rina 2017 Perangkat Pembelajaran Inovatif dalam Pembelajaran IPA Terpadu untuk Menggali Kemampuan Berpikir Kreatif Siswa in Prosiding Seminar Nasional Tahunan Fakultas Ilmu Sosial Universitas Negeri Medan Tahun 2017 pp 425-429

[23] Murnawianto S 2018 Pengembangan Perangkat Pembelajaran IPA Berbasis STEM (Science, Technology, Engineering, and Mathematics) Materi Perpindahan Kalor untuk Meningkatkan Kemampuan Berpikir Logis Universitas Sebelas Maret Surakarta

[24] Mufarriha U 2018 Pengembangan perangkat pembelajaran berbasis Science, Technology, Engineering and Mathematics (STEM) pada sub materi Suhu Universitas Negeri Malang

[25] Becker K and Park K 2011 Effects of integrative approaches among science, technology, engineering, and mathematics ( STEM ) subjects on students' learning: A preliminary meta-analysis $J$. STEM Educ vol 12 no 5 pp 23-38

[26] Silvasailam T 1974 Instructional Development for Training Teachers of Exceptional Children: A Sourcebook Indiana Univ. Bloom Cent. Innov. Teach. Handicap. Natl. Cent. Improv. Educ. Syst. no Mc p 75

[27] Sriyati S 2018 Upaya Mengembangkan Kemampuan Guru Kota Bandung dan Sekitarnya untuk Mendesain Pembelajaran Berbasis STEM (Science Technology, Engineering and Mathematics) Melalui Kegiatan Lokakarya Semin. Nasional Has. PKM LPM Univ. Pas pp 949-963

[28] Madyani I 2019 Pengembangan LKPD IPA Model PBL Terintegrasi STEM in Seminar Nasional Pendidikan Sains 2019 pp 107-113

[29] Zahara M 2018 Implementasi Pendekatan Science, Technology, Engineering, and Mathematics (STEM) untuk Mereduksi Disparitas Gender Pada Penguasaan Konsep Kalor Peserta Didik 
[30] Sujito S K, Shindharatna S D, Wisodo H, Asim K M and Kusairi S 2018 Pengembangan Perangkat Pembelajaran Science, Technology, Engineering and Mathematics Semin. Nas. FST 2018 Univ. Kanjuruhan Malang Pengembang vol 1 pp 718-723 